\title{
PENGEMBANGAN PERANGKAT PEMBELAJARAN \\ DENGAN PENDEKATAN CTL PADA MATERI TEOREMA PYTHAGORAS DI KELAS VIII SEKOLAH MENENGAH PERTAMA
}

\author{
Yafita Arfina Mu'ti ${ }^{1}$, Mardiyana $^{2}$, Dewi Retno Sari Saputro ${ }^{3}$ \\ ${ }^{1,2,3}$ Prodi Magister Pendidikan Matematika, FKIP Universitas Sebelas Maret Surakarta
}

\begin{abstract}
This study aimed to: (1) produce teaching and learning materials with CTL approach on Pythagorean theorem at VIII Grade of Junior High School that was valid, practical, and effective, (2) investigate the better achievement in mathematics, whether using teaching and learning materials of CTL approach than using conventional teaching and learning materials. This study was development research. The development model used in this research was a developmental research by Plomp that contained five phases, (1) preliminary investigation, (2) design, (3) realization/ construction, (4) test, evaluation, and revision, and (5) implementation. Teaching and learning materials said have quality if fulfilled validity, practical, and effective criteria. Teaching and learning materials was categorized validity based on expert judgement. Taeching and Learning materials was categorized practical if based on theory, teaching and learning materials was able to use it without revision or little revision and had fulfilled criteria of a practical teaching and learning materials. Teaching and learning materials was categorized effective if it fulfilled the indicators for a effective learning, including students activity during studying, learning activities based on syntax, student response about the learning, and students learning result. The data in this research was collected using test, questionnaire, observation, documentation, and interview. To investigate the better student achievement used t-test. The results of this study were as follows: teaching and learning materials of CTL approach that include lesson plans, worksheets, and test of learning outcome was said to be valid, practical, and effective. Besides that, student achievement with teaching and learning materials of CTL approach was better than student achievement with teaching and learning materials of conventional approach.
\end{abstract}

Keywords: Teaching and learning materials, CTL, Pythagorean theorem

\section{PENDAHULUAN}

Matematika merupakan ilmu pengetahuan yang mempelajari struktur yang abstrak dan pola hubungan yang ada didalamnya. Belajar matematika pada hakekatnya adalah belajar konsep, struktur konsep dan mencari hubungan antar konsep dan strukturnya, sehingga siswa diarahkan untuk benar-benar memahami konsep yang diajarkan. Namun, selama ini pada kenyataannya hal tersebut tidak didukung oleh situasi dan kondisi pembelajaran matematika di kelas, dimana pembelajaran diawali dengan guru menjelaskan konsep dan dilanjutkan dengan pemberian contoh-contoh soal sehingga siswa kurang mendapat kesempatan untuk berpikir aktif saat pembelajaran. Hal tersebut mengakibatkan siswa hanya mendengarkan ceramah dari guru dan guru juga tidak mempedulikan sebagian siswa yang pemahamannya kurang. Jika seorang guru lebih sering ceramah dan hanya beberapa siswa saja yang memahami maka hal tersebut membuat matematika menjadi kurang bermakna dan membosankan bagi siswa. Kidman 
(2004) mengungkapkan bahwa A teacher must know the students, collectively if not individually. Seorang guru seharusnya mengetahui siswanya secara keseluruhan bukan secara individu. Seorang guru harus mengetahui tingkat pemahaman seluruh siswa terhadap materi yang dipelajari. Seperti yang diungkapkan oleh Mulyasa (2006) tugas guru dalam pembelajaran tidak terbatas pada penyampaian informasi. Pembelajaran matematika hendaknya memberikan kesempatan yang luas kepada siswa untuk terlibat aktif sehingga konsep materi yang dipelajari benar-benar tertanam dan dikuasai oleh siswa dengan baik. Oleh karena itu, dibutuhkan suatu pendekatan matematika yang dapat membuat siswa lebih aktif dalam pembelajaran sehingga siswa tidak cepat merasa bosan dan pembelajaran menjadi lebih bermakna bagi siswa.

Salah satu pendekatan pembelajaran yang dapat membuat siswa lebih aktif dalam pembelajaran, tidak cepat merasa bosan, dan pembelajaran menjadi lebih bermakna bagi siswa adalah pendekatan CTL. Pendekatan CTL merupakan pendekatan pembelajaran yang menghubungan antara aktivitas sehari-hari dengan materi pelajaran matematika. Di dalam Kurikulum Tingkat Satuan Pendidikan (KTSP), pembelajaran matematika hendaknya dimulai dengan pengenalan masalah yang sesuai dengan situasi (contextual problem). Dengan mengajukan masalah kontekstual, siswa secara bertahap dibimbing untuk menguasai konsep matematika. Selanjutnya, siswa diharapkan mampu menerapkan konsep matematika yang dipelajarinya dalam kehidupan sehari-hari atau pada bidang lain. Menurut Satriani, dkk. (2012) pendekatan CTL membantu siswa untuk memecahkan masalah dalam kehidupan sehari-hari. Pendekatan CTL pertama kali dikembangkan di Amerika Serikat yang diawali dengan dibentuknya Washington State Consortium for Contextual oleh Departemen Pendidikan Amerika Serikat. CTL mempunyai tujuh komponen, yaitu konstruktivisme (constructivism), bertanya (questioning), menemukan (inquiry), masyarakat belajar (learning community), pemodelan (modeling), refleksi (reflection), dan penilaian sebenarnya (authentic assessment). Dari hasil penelitian yang dilakukan oleh Sutama, dkk. (2015) pembelajaran dengan menerapkan tujuh komponen pendekatan CTL pada aspek motivasi siswa untuk menciptakan iklim pembelajaran yang kondusif meningkat dari 44,44\% menjadi 75,00\%, pada aspek keterlibatan siswa dalam memberikan pertanyaan meningkat dari $13,89 \%$ menjadi $66,67 \%$, dan pada aspek keterlibatan siswa untuk memecahkan masalah meningkat dari 19,44\% menjadi 72,22\%. Dari data tersebut menunjukkan bahwa pembelajaran dengan menerapkan tujuh komponen pendekatan CTL dapat meningkatkan kualitas pembelajaran matematika yang berdampak positif terhadap prestasi belajar siswa. 
Agar pembelajaran dengan pendekatan CTL bisa terlaksana dengan baik diperlukan perangkat pembelajaran. Tujuan penyusunan perangkat pembelajaran untuk memudahkan guru pada saat proses pembelajaran. Perangkat pembelajaran yang dikembangkan dalam penelitian ini yaitu Rancangan Pelaksanaan Pembelajaran (RPP), Lembar Kegiatan Siswa (LKS), dan Tes Hasil Belajar (THB). Menurut Ampa, dkk. (2013) perangkat pembelajaran kontekstual membantu siswa untuk memperoleh informasi atau pengetahuan dengan cara membuatnya dari yang abstrak menjadi konkret. Materi yang dipilih dalam penelitian ini adalah teorema Pythagoras yang merupakan materi kelas VIII semester ganjil pada kurikulum KTSP. Menurut peneliti materi ini dapat diajarkan menggunakan pendekatan CTL. Dari segi waktu, materi teorema Pythagoras diajarkan di semester ganjil. Dari segi materi, konsep teorema Pythagoras telah dikenal siswa sejak SD, tetapi materi tersebut masih kurang bermakna bagi siswa.

Berdasarkan hasil wawancara dengan beberapa guru Matematika SMP di Kabupaten Madiun diperoleh bahwa untuk memberikan masalah yang kontekstual kepada siswa yang sesuai dengan materi yang dipelajari tidak mudah karena sumber belajar masih terbatas dan sulit untuk mengemas dalam proses pembelajaran. Selain itu, membutuhkan waktu yang lebih banyak, sedangkan materi yang dipelajari cukup banyak. Jadi, selama ini guru lebih memilih untuk mengajarkan matematika dengan pendekatan konvensional, hal tersebut mengakibatkan guru kurang memberikan kesempatan kepada siswa untuk lebih aktif dalam pembelajaran. Berdasarkan hasil dokumentasi perangkat pembelajaran matematika di SMP 2 Dolopo diperoleh bahwa perangkat pembelajaran yang digunakan oleh guru pada saat mengajar merupakan hasil dari MGMP di wilayah Kabupaten Madiun. Dalam perangkat pembelajaran tersebut masih terdapat banyak kekurangan. Komponen-komponen yang ada di RPP masih belum lengkap. Dalam RPP tersebut tidak ada komponen pendekatan pembelajaran, tidak ada motivasi pada saat kegiatan pendahuluan, tidak ada penguatan dari guru, dan tidak ada refleksi di kegiatan penutup. Padahal, keempat komponen tersebut sangat berperan penting dalam pembelajaran. Selanjutnya, Perangkat LKS yang digunakan guru masih kurang baik. Judul yang terdapat dalam LKS belum menggambarkan materi yang akan dipelajari oleh siswa, langkah-langkah kerja dalam LKS terlalu banyak titik-titik termasuk rumus yang seharusnya ditemukan oleh siswa sehingga kurang melatih siswa untuk berpikir kreatif. LKS juga kurang membimbing siswa untuk memahami materi yang dipelajari karena LKS berupa soal-soal yang harus diselesaikan oleh siswa. Perangkat THB yang digunakan hanya terdiri dari soal mudah dan sedang. Selain itu, soal-soal untuk aplikasi dalam kehidupan sehari-hari masih sedikit. Fakta menunjukkan adanya tingkat 
penguasaan dan pemahaman yang rendah pada materi teorema Pythagoras. Data nilai rerata dan persentase ketuntasan belajar siswa pada materi teorema Pythagoras ditunjukkan pada Tabel 1.

Tabel 1. Data Nilai Rerata dan Persentase Ketuntasan Belajar Siswa pada Materi Teorema Pythagoras

\begin{tabular}{lccc}
\hline Tahun Pelajaran & Rerata Ulangan Harian & Ketuntasan Klasikal & Jumlah Siswa \\
\hline $2012 / 2013$ & 67,92 & $41,90 \%$ & 160 \\
$2013 / 2014$ & 64,57 & $36,11 \%$ & 144 \\
$2014 / 2015$ & 61,93 & $30,30 \%$ & 165 \\
\hline
\end{tabular}

Berdasarkan uraian sebelumnya, diperlukan pengembangan perangkat pembelajaran dengan pendekatan CTL pada materi teorema Pythgoras yang meliputi RPP, LKS, dan THB. Perangkat pembelajaran ini memuat tujuh komponen pendekatan CTL. Melalui perangkat pembelajaran dengan pendekatan CTL yang menekankan keaktifan siswa dan membuat pembelajaran menjadi lebih bermakna dapat meningkatkan prestasi belajar siswa.

Perangkat pembelajaran ini dikembangkan berdasarkan model pengembangan Plomp. Model pengembangan Plomp terdiri dari fase investigasi awal (preliminary investigation), fase desain (design), fase realisasi/konstruksi (realization/ construction), fase tes evaluasi dan revisi (tes evaluation and revision), serta fase implementasi (implementation). Model Plomp dipilih karena menurut peneliti model pengembangan Plomp lebih sistematis, terarah, sesuai dengan perangkat pembelajaran yang dikembangkan, dan siklus dari fase pengembangannya sesuai dengan kebutuhan pengembangan perangkat pembelajaran yang diinginkan oleh peneliti.

Penelitian sebelumnya dilakukan oleh Suhartini (2014) yang mengembangkan perangkat pembelajaran matematika dengan pendekatan pembelajaran kontekstual untuk siswa SMK jurusan akuntansi. Pada penelitian tersebut, pendekatan kontekstual didefinisikan sebagai pendekatan yang berpusat pada siswa, pembelajaran dilaksanakan dengan memperhatikan potensi siswa, sarana pembelajaran, situasi, dan kondisi serta memperhatikan tujuan yang ingin dicapai. Padahal secara teori, pendekatan kontekstual harus memuat tujuh komponen kontekstual. Perangkat pembelajaran dalam penelitian ini memuat tujuh komponen pendekatan CTL, yaitu konstruktivisme, bertanya, menemukan, masyarakat belajar, pemodelan, refleksi, dan penilaian sebenarnya. 


\section{METODE PENELITIAN}

Penelitian ini termasuk jenis penelitian pengembangan karena peneliti mengembangkan perangkat pembelajaran dengan pendekatan CTL pada materi teorema Phytagoras. Perangkat pembelajaran yang dikembangkan yaitu RPP, LKS, dan THB. Model pengembangan yang digunakan dalam penelitian ini adalah model pengembangan Plomp yang terdiri dari 5 fase, yaitu: 1) investigasi awal; 2) desain; 3) realisasi; 4) tes evaluasi dan revisi, dan 5) implementasi. Pada fase investigasi awal dilakukan analisis masalah, analisis teori, analisis kurikulum, analisis materi, dan analisis siswa. Tempat penelitian ini dilaksanakan di SMP N 2 Dolopo. Waktu pelaksanaan penelitian dimulai pada sekitar bulan Juli 2015 sampai dengan bulan Januari 2016. Objek penelitian ini adalah perangkat pembelajaran yang dikembangkan yaitu RPP, LKS, dan THB. Subjek penelitian ini adalah siswa kelas VIII SMP N 2 Dolopo kelas VIII G. Subjek dalam penelitian ini dijadikan sampel penelitian.

Pengumpulan data dilakukan melalui: (1) metode tes, untuk mengukur prestasi belajar siswa, (2) metode angket dan lembar pengamatan, untuk mengukur keaktifan siswa, keterlaksanaan sintaks pembelajaran, dan respon siswa terhadap pembelajaran, (3) metode dokumentasi, untuk mengetahui data kemampuan awal siswa, (4) metode wawancara, untuk mengetahui metode pembelajaran yang digunakan oleh guru pada saat pembelajaran di kelas.

Instrumen yang digunakan dalam penelitian ini adalah: (1) lembar validasi RPP digunakan untuk mengumpulkan data tentang penilaian validator terhadap RPP, (2) lembar validasi LKS digunakan untuk mengumpulkan data tentang penilaian validator terhadap LKS, (3) lembar validasi THB digunakan untuk mengumpulkan data tentang penilaian validator terhadap THB, (4) lembar pengamatan aktivitas siswa digunakan untuk mengumpulkan data tentang aktivitas siswa pada saat proses pembelajaran di kelas, (5) lembar pengamatan keterlaksanaan sintaks pembelajaran digunakan untuk mengumpulkan data tentang aktivitas-aktivitas pada saat proses pembelajaran di kelas, (6) lembar angket respon siswa digunakan untuk mengumpulkan data tentang pendapat siswa terhadap pelaksanaan pembelajaran, (7) lembar tes final digunakan sebagai tes prestasi belajar untuk membandingkan antara prestasi belajar kelas eksperimen dan prestasi belajar kelas kontrol, dan (8) lembar angket respon guru digunakan untuk mengumpulkan data tentang pendapat guru terhadap perangkat pembelajaran yang telah dikembangkan.

Dalam penelitian ini dilakukan uji coba terbatas terlebih dahulu sebelum uji coba yang sebenarnya. Tujuan dilakukannya uji coba terbatas adalah untuk mengetahui kelayakan perangkat pembelajaran, keterbacaan perangkat pembelajaran yang telah 
dikembangkan, dan keterlaksanaan kegiatan pembelajaran. Sampel untuk tahap uji coba terbatas yaitu 20 siswa kelas VIII D SMP N 2 Dolopo. Tahap uji coba dilakukan di dua kelas yaitu kelas VIII G sebanyak 25 siswa sebagai kelas eksperimen yang dikenai pembelajaran dengan perangkat pembelajaran CTL dan kelas VIII E sebanyak 22 siswa sebagai kelas kontrol yang dikenai pembelajaran dengan perangkat pembelajaran konvensional.

Validasi perangkat pembelajaran dengan pendekatan CTL menggunakan rata-rata total kevalidan. Uji untuk mengetahui prestasi belajar siswa antara kelompok eksperimen dan kelompok kontrol menggunakan statistik uji t.

\section{HASIL PENELITIAN DAN PEMBAHASAN}

Pengembangan perangkat pembelajaran matematika dengan pendekatan CTL pada materi teorema Pythagoras yang telah dilakukan menggunakan model pengembangan Plomp. Hasil pengembangan perangkat pembelajaran pada fase investigasi awal diperoleh permasalahan-permasalahan pada saat proses pembelajaran matematika yang terdapat di SMP N 2 Dolopo, diantaranya: (1) guru kesulitan untuk memberikan masalah yang kontekstual pada siswa yang sesuai dengan materi yang dipelajari karena sumber belajar pendukung pembelajaran sebagai referensi yang tersedia masih terbatas; (2) kenyataan proses pembelajaran tidak sesuai dengan langkah-langkah proses pembelajaran di RPP sehingga belum sesuai dengan kondisi dan kebutuhan pembelajaran; (3) guru kurang memberikan kesempatan kepada siswa untuk lebih aktif dalam proses pembelajaran; (4) siswa kelas VIII terbiasa belajar secara pasif, siswa hanya mendengarkan ceramah dari guru dan mencatat materi yang disampaikan oleh guru; (5) komponen-komponen perangkat pembelajaran yang digunakan guru kurang lengkap; dan (6) nilai rata-rata materi teorema Pythagoras pada tiga tahun berturut-turut masih rendah.Selanjutnya, pada analisis teori dilakukan pencarian literatur untuk mengkaji teoriteori terkait dengan permasalahan pembelajaran matematika yang terjadi dan diperoleh teori pendekatan CTL karena pendekatan CTL dapat menyelesaikan masalah yang terjadi dalam pembelajaran matematika yang terjadi di SMP N 2 Dolopo. Pendekatan CTL merupakan pendekatan pembelajaran yang mengaitkan antara materi pembelajaran dengan permasalahan-permasalahan yang terjadi dalam kehidupan sehari-hari. Pendekatan CTL mempunyai tujuh komponen yaitu konstuktivisme (constructivism), menemukan (inquiry), bertanya (questioning), masyarakat belajar (learning community), pemodelan (modeling), refleksi (reflection), penilaian sebenarnya (authentic assessment). Analisis kurikulum diperoleh kurikulum yang berlaku di SMP Negeri 2 Dolopo adalah 
Kurikulum KTSP. Dari hasil analisis materi diperoleh indikator pencapaian hasil belajar dalam penelitian ini yaitu: (1) menemukan teorema Pythagoras, (2) menyatakan teorema dalam bentuk teorema Pytagoras, (3) membuktikan teorema Pythagoras, (4) menghitung panjang salah satu segitiga siku-siku jika dua sisi yang lain diketahui, (5) menghitung panjang diagonal pada bangun datar persegi, persegi panjang, belah ketupat, layanglayang, dan sebagainya, dan (7) menyelesaikan permasalahan pada bangun datar yang penyelesaiannya menggunakan teorema Pythagoras. Dari hasil analisis siswa diperoleh kemampuan akademik siswa heterogen dan selama ini pengetahuan siswa bersumber dari guru sehinngga siswa kurang aktif dalam pembelajaran. Pada fase desain diperoleh rancangan perangkat pembelajaran dengan pendekatan CTL pada materi teorema Pythagoras yang meliputi RPP, LKS, dan THB. RPP dilakukan dalam lima kali pertemuan. Kegiatan utama yang dilakukan untuk pertemuan pertama, kedua, ketiga secara berturut-turut adalah mengerjakan LKS 1, LKS 2, LKS 3, untuk pertemuan keempat siswa mengerjakan THB dengan pendekatan CTL, dan pertemuan terakhir siswa mengerjakan THB final serta mengisi angket respon siswa. Terdapat 3 LKS yang dirancang, untuk LKS 1 membahas tentang menemukan teorema Pythagoras, menyatakan teorema Pythagoras dalam bentuk rumus teorema Pythagoras, dan menemukan Tripel Pythagoras, untuk LKS 2 membahas tentang membuktikan teorema Pythagoras dan menghitung panjang salah satu sisi segitiga siku-siku jika dua sisi yang lain diketahui, untuk LKS 3 membahas tentang menghitung panjang diagonal bangun datar dengan menggunakan teorema Pythagoras dan menyelesaikan permasalahan pada bangun datar yang penyelesaiannya menggunakan teorema Pythagoras. THB terdiri dari 20 soal pilihan ganda dan 5 soal uraian. Hasil fase realisasi dan konstruksi diperoleh perangkat pembelajaran dengan pendekatan CTL pada materi teorema Pythagoras yang meliputi RPP, LKS, dan THB, serta instrumen penelitian. Hasil fase tes, evaluasi, dam revisi diperoleh hasil validasi perangkat pembelajaran dengan pendekatan CTL pada materi teorema Pythagoras. Terdapat 3 validator yang memvalidasi perangkat pembelajaran. Berdasarkan hasil validasi diperoleh RPP yang dikembangkan termasuk dalam kategori "sangat valid" dengan rerata penilaian validator yaitu 4,5, LKS yang dikembangkan termasuk dalam kategori "sangat valid" dengan skor rerata penilaian validator yaitu 4,4, dan hasil validitas isi menunjukkan bahwa perangkat mempunyai validitas tinggi. Selanjutnya, dari hasil uji reliabilitas perangkat THB matematika ini diperoleh indeks reliabilitas untuk soal pilihan ganda yaitu sebesar 0,7077 dan indeks reliabilitas soal uraian sebesar 0,7034 sehingga dapat dinyatakan THB reliabel. Berdasarkan hasil perhitungan tingkat kesukaran dari 20 butir soal pilihan ganda, diperoleh 4 butir soal yang 
tidak memenuhi kriteria soal yang baik dengan tingkat kesukaran masing-masing 0,75 ; 0,8 ; 0,8 ; dan 0,75 yang masing-masing berturut-turut nomor $3,4,8$, dan 11 . Hasil perhitungan daya pembeda dalam uji coba 20 butir soal pilihan ganda tes hasil belajar matematika terhadap 20 siswa diperoleh 5 butir soal yang tidak memenuhi yaitu nomor 0,$1 ;-0,2 ; 0 ; 0 ; 0,1$, secara berturut-turut nomor $2,4,5,8$, dan 11 . Untuk soal uraian semua soal memenuhi kriteria soal yang baik. Dari data yang telah diuraikan dapat disimpulkan bahwa ketiga perangkat pembelajaran yaitu RPP, LKS, dan THB dinyatakan valid.

Hasil penilaian kepraktisan berdasarkan kriteria diperoleh rata-rata kepraktisan RPP sebesar 4,3 sehingga RPP yang dikembangkan termasuk dalam kategori "sangat praktis". Hasil kepraktisan LKS dengan pendekatan CTL berdasarkan kriteria diperoleh rata-rata kepraktisan LKS sebesar 4,3 sehingga LKS yang dikembangkan termasuk dalam kategori "sangat praktis". Hasil kepraktisan THB dengan pendekatan CTL berdasarkan kriteria diperoleh rata-rata kepraktisan THB sebesar 4,225 sehingga THB yang dikembangkan termasuk dalam kategori "sangat praktis". Selain dari rata-rata kepraktisan, ketiga validator memberikan nilai B untuk RPP, LKS, dan THB yang berarti perangkat pembelajaran dapat digunakan dengan sedikit revisi. Jadi, dapat disimpulkan bahwa ketiga perangkat pembelajaran dengan pendekatan CTL yang meliputi RPP, LKS, dan THB dinyatakan praktis.

Berdasarkan hasil pengamatan aktivitas siswa yang diamati setiap 5 menit sekali diperoleh bahwa siswa cenderung lebih aktif dalam pembelajaran menggunakan perangkat dengan pendekatan CTL. Hasil pengamatan keterlaksaaan RPP dengan pendekatan CTL diperoleh pada pertemuan pertama, kedua, ketiga secara berturut-turut 92\%, 92\%, 100\% langkah-langkah dalam RPP sudah terlaksana. Dengan demikian, keterlaksanaan RPP termasuk kategori "baik" dengan nilai rata-rata keseluruhan 3,21. Ketuntasan hasil belajar siswa kelas VIII G sebagai kelas eksperimen dari 25 siswa dan kelas VIII E sebagai kelas eksperimen dari 22 siswa diperoleh data yang disajikan dalam Tabel 2.

Tabel 2. Ketuntasan Hasil Belajar Siswa

\begin{tabular}{llrr}
\hline \multirow{2}{*}{ Kelas } & Uraian & Jumlah & Persentase \\
\hline \multirow{2}{*}{ VIII G } & Siswa Tuntas & 23 & $92,00 \%$ \\
\cline { 2 - 4 } & Siswa Tidak Tuntas & 2 & $8,00 \%$ \\
\hline \multirow{2}{*}{ VIII E } & Siswa Tuntas & 19 & $86,36 \%$ \\
\cline { 2 - 4 } & Siswa Tidak Tuntas & 3 & $13,64 \%$ \\
\hline
\end{tabular}


Berdasarkan Tabel 2 diperoleh bahwa ketiga perangkat pembelajaran dengan pendekatan CTL yang meliputi RPP, LKS, dan THB dinyatakan efektif. Selanjutnya, hasil uji coba terbatas perangkat pembelajaran diperoleh beberapa kendala dalam proses pelaksaan pembelajarannya. Kendala-kendala yang muncul antara lain: alokasi waktu tidak cukup, keadaan kelas kurang terkondisikan, siswa banyak yang ramai, dan siswa belum terbiasa dengan pembelajaran berkelompok. Dari kendala-kendala di atas, peneliti memperbaiki proses pembelajaran sehingga nantinya pada saat dilakukan uji coba dilaksanakan di kelas VIII G proses pembelajaran dapat terlaksana dengan baik. Dari tahap uji coba perangkat pembelajaran ini, diperoleh: (1) langkah-langkah proses pembelajaran dengan perangkat pembelajaran CTL dapat terlaksana dengan baik, sesuai yang terdapat dalam RPP, (2) siswa dapat mengerjakan dan menyelesaikan LKS 1, LKS 2, dan LKS 3 dengan baik meskipun masih terdapat beberapa kesalahan yang dilakukan oleh siswa, (3) Siswa mengerjakan tes hasil belajar dengan pendekatan CTL dan tes hasil belajar yang digunakan untuk pembanding dengan baik.

Langkah selanjutnya adalah uji efektivitas pembelajaran dari hasil uji coba. Langkah awal uji efektivitas adalah uji keseimbangan. Sebelum dilakukan uji keseimbangan dilakukan uji normalitas dan uji homogenitas terlebih dahulu. Uji normalitas dilakukan untuk mengetahui apakah populasinya berdistribusi normal atau tidak. Uji normalitas dilakukan menggunakan metode Liliefors karena data yang diperoleh tidak dalam distribusi frekuensi bergolong. Data yang digunakan dalam uji normalitas ini adalah data kemampuan awal yang diperoleh dari nilai Ulangan Tengah Semester kelas VIII SMP N 2 Dolopo tahun pelajaran 2015/2016. Hasil analisis uji normalitas kemampuan awal siswa ditunjukkan pada Tabel 3.

Tabel 3. Rangkuman Hasil Uji Normalitas Data Kemampuan Awal Siswa

\begin{tabular}{lrrll}
\hline Pembelajaran & $\boldsymbol{L}_{\text {hitung }}$ & $\boldsymbol{L}_{\text {tabel }}$ & Keputusan Uji & Kesimpulan \\
\hline CTL & 0,1531 & 0,173 & $H_{0}$ tidak ditolak & Normal \\
Konvensional & 0,1355 & 0,201 & $H_{0}$ tidak ditolak & Normal
\end{tabular}

Berdasarkan Tabel 3, diperoleh bahwa nilai $L_{\text {hitung }}$ bukan anggota dari DK sehingga $H_{0}$ tidak ditolak. Jadi, dapat disimpulkan bahwa kedua sampel berasal dari populasi yang berdistribusi normal. 
Uji homogenitas dilakukan untuk mengetahui apakah variansi-variansi dari sejumlah populasi sama atau tidak. Uji homogenitas dalam penelitian ini menggunakan uji Bartlett dengan tingkat signifikasi 5\%. Berdasarkan hasil perhitungan uji homogenitas diperoleh untuk nilai $\chi_{\text {hitung adalah }}^{2} 0,085$ dan untuk nilai $\chi_{\text {tabel }}^{2}$ adalah 3,841 . Selanjutnya, karena $\chi_{\text {hitung }}^{2}$ bukan anggota DK maka $H_{0}$ tidak ditolak. Dengan demikian, dapat ditarik kesimpulan bahwa variansi-variansi dari kedua populasi sama. Berdasarkan hasil uji keseimbangan diperoleh untuk $t_{\text {hitung }}$ sebesar 0,0932 dan $t_{\text {tabel }}$ sebesar 2,0141, karena $t_{\text {hitung }} \notin D K$ maka $H_{0}$ tidak ditolak. Dengan demikian, dapat disimpulkan kedua populasi mempunyai kemampuan awal yang sama.

Hasil uji prestasi belajar siswa diperoleh dari nilai siswa setelah mengerjakan Tes Final. Uji normalitas tes prestasi belajar siswa pada materi teorema Pythagoras pada kelas kontrol diperoleh nilai $L_{\text {hitung }}$ adalah 0,1554 dan nilai $L_{\text {tabel }}$ adalah 0,201. Karena $L_{\text {hitung }}$ bukan anggota dari DK maka $H_{0}$ tidak ditolak. Jadi dapat disimpulkan bahwa sampel kelas kontrol ini berasal dari populasi berdistribusi normal. Uji normalitas tes prestasi belajar siswa pada materi teorema Pythagoras di kelas eksperimen diperoleh nilai untuk $L_{\text {hitung }}$ adalah 0,1148 dan nilai untuk $L_{\text {tabel }}$ adalah 0,173. Karena $L_{\text {hitung }}$ bukan anggota dari DK maka $H_{0}$ tidak ditolak. Jadi dapat disimpulkan bahwa sampel kelas eksperimen ini berasal dari populasi berdistribusi normal.

Hasil uji homogenitas tes prestasi belajar siswa pada kelompok eksperimen dan kelompok kontrol diperoleh nilai $\chi_{\text {hitung }}^{2}$ adalah 3,404 dan $\chi_{\text {tabel }}^{2}$ adalah 3,841, sehingga $\chi_{\text {hitung }}^{2}$ bukan anggota dari DK. Berdasarkan data diperoleh bahwa $H_{0}$ tidak ditolak, jadi dapat ditarik kesimpulan bahwa sampel yang diambil berasal dari populasi yang mempunyai variansi yang sama. Berdasarkan hasil uji hipotesis dengan uji $t$ diperoleh $t_{\text {hitung }}$ sebesar 3,586 dan $t_{\text {tabel }}$ sebesar 1,67943 sehingga $t_{\text {hitung }} \in$ $D K$. Selain itu, jika dilihat dari rerata nilai siswa di kelas eksperimen lebih tinggi yaitu 79,6 dibandingkan dengan rerata kelas kontrol yaitu 73,7. Jadi dapat ditarik kesimpulan bahwa prestasi belajar siswa dengan perangkat pembelajaran pendekatan CTL lebih baik dari prestasi belajar siswa dengan perangkat pembelajaran pendekatan konvensional.

Hasil fase implementasi diperoleh respon guru terhadap perangkat pembelajaran yang dikembangkan. Menurut pendapat 4 guru matematika diperoleh RPP, LKS, dan THB yang dikembangkan sudah dapat membantu dalam proses pembelajaran karena komponen-komponen yang terdapat dalam RPP sudah memberikan kemudahan bagi guru dan siswa dalam proses pembelajaran dan memberikan peluang yang lebih luas kepada siswa untuk lebih aktif pada saat proses pembelajaran, komponen-komponen dalam LKS 
memberikan kemudahan siswa untuk memahami materi yang dipelajari, dan THB yang dikembangkan sudah bisa digunakan untuk mengukur indikator pencapain hasil belajar siswa.

Proses pengembangan perangkat pembelajaran dengan pendekatan CTL pada materi teorema Pythagoras dilakukan melalui model pengembangan Plomp yang terdiri dari lima fase yaitu fase investigasi awal, desain, realisasi/konstruksi, tes evaluasi dan revisi, dan implementasi. Pengembangan perangkat pembelajaran dengan pendekatan CTL pada materi teorema Pythagoras memenuhi kriteria valid, praktis, dan efektif. Kriteria valid diperoleh dari hasil skor rerata penilaian validator terhadap RPP dan LKS yang termasuk dalam kategori sangat valid dan hasil validitas isi THB yang mempunyai validitas tinggi. Kriteria praktis diperoleh dari penilaian ahli (validator) yang menyatakan bahwa ketiga perangkat pembelajaran dengan pendekatan CTL yaitu RPP, LKS, dan THB dapat digunakan dengan sedikit revisi dan telah memenuhi kriteria kepraktisan. Kriteria efektif diperoleh dari hasil pengamatan keterlaksanaan RPP yang langkah-langkah dalam RPP telah terlaksanan dengan baik, aktivitas siswa pada saat proses pembelajaran dengan perangkat pembelajaran dengan pendekatan CTL lebih aktif, respon positif siswa terhadap pembelajaran, dan ketuntasan hasil belajar siswa yang hampir siswa satu kelas tuntas semua. Hasil penelitian ini sesuai dengan hasil penelitian yang dilakukan oleh Supriyono (2014) yang mengembangkan perangkat pembelajaran matematika model Student Facilitator and Explaining dengan setting CTL pada subpokok bahasan prisma dan limas di kelas VIII SMP dan menghasilkan perangkat pembelajaran yang meliputi RPP, LKS, dan THB yang memenuhi kriteria kevalidan, kepraktisan, dan keefektifan. Selain itu, hasil penelitian ini juga sesuai dengan penelitian yang dilakukan oleh Rif'an (2013) terkait pengembangan perangkat pembelajaran dengan pendekatan kontekstual setting kooperatif tipe Two Stay Two Stray pada subpokok bahasan persegi panjang dan persegi. Dari hasil penelitiannya diperoleh bahwa perangkat pembelajaran yang dikembangkan telah layak digunakan karena telah memenuhi kriteria valid, praktis, dan efektif.

Berdasarkan hasil uji efektivitas diperoleh bahwa prestasi belajar siswa yang dikenai pembelajaran dengan perangkat pembelajaran pendekatan CTL lebih baik dari prestasi belajar siswa yang dikenai pembelajaran dengan perangkat pembelajaran pendekatan konvensional. Salah satu faktor peningkatan prestasi belajar siswa terjadi karena adanya diskusi siswa dalam kelompok. Jika dikaitkan dengan pendekatan CTL, maka diskusi kelompok termasuk dalam komponen masyarakat belajar. Dengan adanya diskusi kelompok siswa menjadi lebih aktif dalam pembelajaran matematika sehingga 
siswa lebih memahami materi yang dipelajari. Hal ini sesuai dengan penelitian yang dilakukan oleh Nartani, dkk. (2015) yang menyatakan bahwa kemampuan komunikasi matematika siswa dapat ditingkatkan melalui pembelajaran kontekstual karena melalui pembelajaran kontekstual siswa mampu membangun konsep, ide, pengetahuan, dan gambaran nyata dengan kalimat matematika. Indikator peningkatan kemampuan komunikasi dilihat dari siswa dapat menyatakan ide melalui kalimat matematika dan berdiskusi secara aktif. Dengan kemampuan tersebut siswa dapat meningkatkan prestasi belajarnya.

\section{SIMPULAN DAN SARAN}

Berdasarkan hasil penelitian pengembangan perangkat pembelajaran matematika dengan pendekatan CTL pada materi teorema Pythagoras di kelas VIII SMP N 2 Dolopo, dapat ditarik kesimpulan pengembangan perangkat pembelajaran dalam penelitian ini dikembangkan dengan menggunakan model pengembangan Plomp yang terdiri dari lima fase, yaitu fase investigasi awal, desain, realisasi/konstruksi, tes evaluasi, dan revisi, serta implementasi. Berdasarkan hasil penelitian, diperoleh perangkat pembelajaran matematika yang meliputi RPP, LKS, dan THB dengan mengaplikasikan tujuh komponen pendekatan CTL telah memenuhi kriteria valid, praktis, dan efektif. Kriteria valid berdasarkan penilaian dari validator. Kriteria praktis berdasarkan hasil penilaian praktisi secara teori perangkat pembelajaran memenuhi kriteria kepraktisan dan perangkat pembelajaran dinyatakan dapat digunakan dengan sedikit revisi. Kriteria efektif diperoleh dari hasil aktivitas siswa selama proses pembelajaran tergolong efektif, keterlaksanaan sintaks pembelajaran selama berlangsungnya pembelajaran sebagian besar terlaksana dengan baik, respon siswa terhadap pembelajaran dengan menggunakan perangkat pembelajaran dengan pendekatan CTL adalah positif, dan ketuntasan hasil belajar siswa yang sebagian besar siswa tuntas. Setelah dilakukan uji hipotesis pada fase tes, evaluasi, dan revisi diperoleh prestasi belajar siswa yang dikenai pembelajaran dengan perangkat pembelajaran pendekatan CTL lebih baik dari prestasi belajar siswa yang dikenai pembelajaran dengan perangkat pembelajaran pendekatan konvensional. Selanjutnya dari hasil fase implementasi, empat guru matematika di Kabupaten Madiun menyatakan bahwa perangkat pembelajaran dengan pendekatan CTL sudah dapat membantu dalam proses pembelajaran dan bisa dijadikan perangkat pembelajaran utama dalam pembelajaran matematika. Dengan demikian, perangkat pembelajaran dengan pendekatan CTL yang meliputi RPP, LKS, dan THB dapat digunakan secara efektif dalam proses pembelajaran matematika. 
Berdasarkan hasil penelitian, penulis memberikan saran untuk guru matematika agar dapat melengkapi perangkat dengan komponen- komponen yang dapat memudahkan guru dalam menyampaikan materi, memotivasi siswa untuk lebih tertarik mengikuti proses pembelajaran, dan memudahkan siswa dalam memahami materi yang disampaikan oleh guru. Di samping itu, Guru dapat menyusun perangkat pembelajaran dengan pendekatan CTL dan menerapkannya dalam proses pembelajaran. Selanjutnya, dalam proses pembelajaran guru hendaknya memberikan kesempatan kepada siswanya untuk mengembangkan pengetahuan yang dimiliki dan mendorong siswa untuk mengaitkan pengetahuan yang dimiliki dengan permasalahan dalam kehidupan sehari-hari. Bagi peneliti lainnya dapat melanjutkan penelitian pengembangan perangkat pembelajaran dengan pendekatan CTL pada materi yang lain.

\section{DAFTAR PUSTAKA}

Ampa, A, T, Basri, M, dan Andriani, A. 2013. The Development of Contextual Learning Materials for the English Speaking Skills. International Journal of Education and Research. 1(9). 1-10.

Kidman, J. 2004. Teaching and Learning: Mapping the Contextual Influences. International Education Journal. 5(3). 331-343.

Mulyasa, E. 2006. Menjadi Guru Profesional: Menciptakan Pembelajaran Kreatif dan Menyenangkan. Bandung: PT. Remaja Rosdakarya.

Nartani, C., Hidayat R. A., dan Yohana, S. Communication in Mathematics Contextual. International Journal of Innovation and Research in Educational Sciences. 2(4). 284-287.

Rif'an, A., Dinawati, T.,dan Nurcholif, D. S. L. Pengembangan Perangkat Pembelajaran Matematika dengan Pendekatan Kontekstual Setting Kooperatif Tipe Two Stay Two Stray Subpokok Bahasan Persegi Panjang dan Persegi Kelas VII SMP. Jember: Universitas Jember.

Satriani, I., Emilia, E., dan Gunawan, M. H. 2012. Contextual Teaching and Learning Approach to Teaching Writing. Indonesian Journal of Applied Linguistics. 2(1). $10-22$.

Supriyono, Setiawan, dan B. Trapsilsiwi, D. 2014. Pengembangan Perangkat Pembelajaran Matematika Model Student Facilitator and Explaining Setting Contextual Teaching and Learning (CTL) pada Subpokok Bahasan Prisma dan Limas Kelas VIII Semester Genap. Jember: Universitas Jember.

Sutama, Samino, dan Narimo, S. 2015. Lesson Study Based Contextual Mathematics Learning Quality in Elementary School of Selo Boyolali. American International $\begin{array}{llll}\text { Journal of } & \text { Social } & \text { Science. } & 4(3) .\end{array}$ 